\title{
Black Swan Sticking out in Turkish Banking Sector
}

\author{
Hasan GOCEN ${ }^{*}$, Halit AKTURK ${ }^{* *}$, Mehmet ORHAN ${ }^{* * *}$
}

\begin{abstract}
This article explores different aspects of an extraordinary event in Turkish banking sector: politically motivated seizure of Bank Asya by the state. We present how political motives play a key role in such an exceptional expropriation ignoring pillars of economic freedom. The attitude of the governing Justice and Development Party (AKP) on democratization path of Turkey is presented for further elaboration to bring revealing insight. Financial statement of Asia Participation Bank Inc. (Bank Asya) is detailed to indicate absence of economic ground for seizure. Our analysis on Bank Asya along with references to similar events and their repercussions point out possible severe legal enforcements against government authorities with political more than justice concerns and prejudgment.
\end{abstract}

Keywords: Bank Asya, Seizure, Financial Statement, Banking Regulation and Supervision Agency, Savings Deposit Insurance Fund

JEL Code Classification: G21; G28; G33; G38

UDC: $336.71(560): 323$

\footnotetext{
*Department of Economics, Melikşah University, Kayseri, Turkey, E-mail: hgocen@meliksah.edu.tr ** Department of Economics, Melikşah University, Kayseri, Turkey, E-mail: hakturk@meliksah.edu.tr ${ }^{* * *}$ Corresponding author, Department of Economics, Fatih University, Istanbul, Turkey, E-mail: morhan@fatih.edu.tr.
} 


\section{Introduction}

'Lynching' is usually defined as punishing someone or a group for supposed offence without a legal trial ${ }^{1}$. The term 'lynching' is embodied by killings and acts of violence against African Americans during the American Civil War between the Union (almost all northern and western states) and the Confederate States of America. In modern times, 'lynching' is often used to describe the fierce execution of political power against a group and associated institutions with certain reserves and opposing views to the political party in power. Recent episodes mention that financial sector is not an exception. Number of private enterprises including banks and financial institutions across the globe operate under political restraints especially in less developed countries where companies, banks and financial institutions perceived to be at the opposite wing are subject to 'lynching' campaigns by political authorities with excessive power.

Politically motivated 'lynching' campaigns towards banks usually start with public statements to damage balance sheet of the targeted banks followed by management takeover by the state fund even though no capital or liquidity problem exists. In this paper, we undertake a case study annexed with historical records to discuss detrimental implications of bank seizures on financial stability when such actions are taken with no reference to rational economic and financial ratio evaluations. Our analysis stand on three fundamental principles: violation of private property rights, financial contagion nature of happenings in the financial sector, and costly bank seizure without economic and financial grounds.

\section{Banking Sector and International Capital Standards}

The banking sector serves three important functions in an economy. First, it acquires funds and acts as an efficient channel for the flow of funds between the economic agents. Second, it motivates economic agents to save by offering attractive returns. And third, it gathers savings and creates loans to entrepreneurs undertaking investment projects. Thus, banks are considered cost reducing financial intermediaries acting between depositors (surplus units) and borrowers (deficit units) in a market economy (Ritter, Silber, and Udell, 2009).

The banks operate in a sector which is constantly monitored and regulated to ensure liquidity and solvency. In addition, banks are generally subject to minimum capital requirements based on a set of international capital standards, known as the Basel Accords. The Basel Accords refer to the banking supervision recommendations on banking regulations issued by the Basel Committee on Banking Supervision (BCBS). Capital adequacy is the main focus of the Committee's activities where Basel Accords are constantly updated responding to lessons

\footnotetext{
${ }^{1}$ Finkelman (2006) discusses the term 'lynching' originated from the name Charles Lynch, a militia officer and head of an irregular court in Virginia, who ordered extralegal punishment for American colonists remained loyal to the British monarchy during the American Revolutionary War.
} 
derived from experiences of financial crisis, changing risk structure and raised needs for a more stable banking sector. Basel Accord I approved on July 1988 called for banks to maintain a minimum capital ratio of capital to risk-weighted assets of $8 \%$ effective by the end of 1992 . Although minimum capital requirement is still maintained at 8\% in Basel II of June 2004 and Basel III of September 2010, substantial changes are made in the methodology for calculation of risk-weighted assets and definition of capital, respectively (Kubat, 2014).

\subsection{Banking Sector and Participation Banks in Turkey}

The Turkish banking sector consists of deposit banks, development and investment banks, and participation banks operating under profit/loss sharing principles. Although the history of Money Trusts, the institutions where the principles of participation banking were implemented the first time, is long lying back to $16^{\text {th }}$ century Ottomans, the introduction of the Turkish banking sector with participation banks is relatively recent phenomenon. Participation banks began to operate in Turkey in 1983 under the name of "Special Finance Houses" (SFHs) ${ }^{2}$. Initial establishments in the sector were Al-Baraka Turk and Faisal Finance House both of which were founded in 1984. A third competitor, Kuveyt Türk Finance House entered the sector in 1988. The entrance of Anadolu Finance House, the first SFH with one hundred percent domestic capital, in 1991 is considered a milestone for participation banking in Turkey. Few years after Anadolu Finance, domestically owned Ihlas Finance and Asya Finance House were established in 1995 and 1996, respectively. El-Gamal and Inanoğlu (2000) present an overview of participation banks in Turkey and evolution of their legal status over time.

As of December 2014, thirty four deposit banks, thirteen development and investment banks, and four participation banks offer services in Turkey ${ }^{3}$. Deposit banking dominates the banking sector where asset share is a little over ninety percent as shown in Figure 1. The asset share of participation banks, development and investment banks has changed dramatically over the periods of 2005 to 2014 . The asset share of participation banks have raised from 2 to 5 percent whereas those of development and investment banks have risen from 3 to 4 percent as depicted in Figure 1. The four participation banks' assets account for 104.3 billion TL corresponding a little over five percent of total asset size in the Turkish banking sector. Overall asset size of the banking sector grew from 406 billion TL in Dec. 2005 to 1994 billion TL in December 2014 corresponding about 20 percent annual growth on average.

\footnotetext{
${ }^{2}$ Special Finance Houses (SFHs) were transformed into Participation Banks by a regulatory amendment to Banking Law No. 5411 in November 2005 when SFHs gained 'bank' status.

${ }^{3}$ The participation banks in Turkey are Albaraka Türk, Bank Asya, Kuveyt Türk, and Türkiye Finans. Asya Finance House of 1996 was transformed into Bank Asya. Faisal Finance founded in 1984 was transformed into Family Finance which merged with Anadolu Finance in 2005 to form Türkiye Finans. The Ihlas Finance operations, on the other hand, were shut down by the Banking Regulation and Supervision Agency of Republic of Turkey in August 2000.
} 


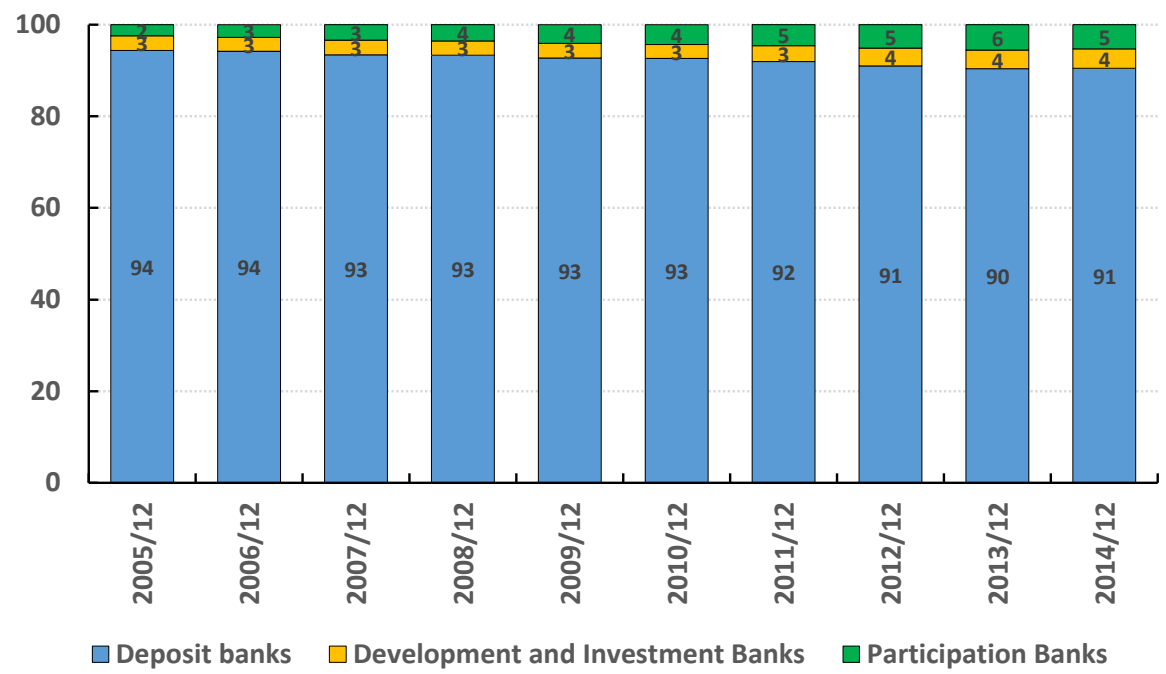

Figure 1. Banking sector assets by groups (\%)

Source: Banking Regulation and Supervision Agency (BDDK) of Republic of Turkey.

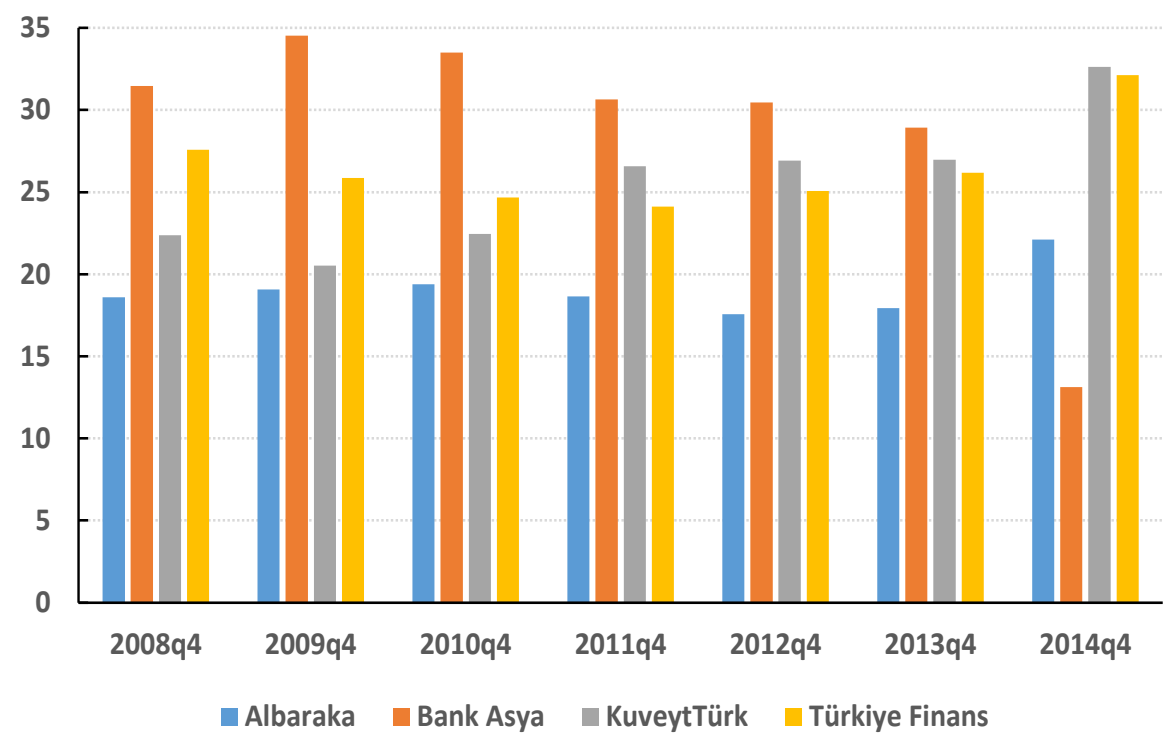

Figure 2. Assets by participant bank (\%)

Source: The Participation Banks Association of Republic of Turkey. 
Members of participation banks in Turkey are Albaraka Türk Participation Bank Inc. (Albaraka Türk), Asia Participation Bank Inc. (Bank Asya), Kuwait Turk Participation Bank Inc. (Kuveyt Türk), and Turkey Finance Participation Bank Inc. (Türkiye Finans) as of January 31 2015. Asset-wise comparison among participation banks in Turkey reveals that Bank Asya leads the sector with a peak asset size of 11.6 billion TL (35 percent of the market) in the last quarter of 2009 during the periods of 2008Q4 to 2014Q4. Significant outflows started in 2014 mainly due to government orchestrated "state companies and government supporters closing their accounts" dropped Bank Asya's assets by half from a maximum of 27.7 billion TL in the last quarter of 2013 to 13.6 billion TL by the end of 2014, costing the bank being Turkey's leading Islamic lender (O'Byrne, 2014).

\subsection{Regulatory Institutions in Turkey}

Up until the millennium, the Turkish banking sector used to be monitored and governed by two primary regulatory and executive authorities: the Central Bank of the Republic of Turkey (CBRT) and Savings Deposit Insurance Fund (TMSF). TMSF was established in 1983 but its independent and separate institutional status was granted only after December 2003 by a legislative amendment. Prior to gaining its independent status, TMSF was administered and represented by the CBRT and Banking Regulation and Supervision Agency (BDDK) over 1983-1999 and 19992003, respectively. The main function of the TMSF is to provide insurance for deposit and participation accounts to protect account owners' rights and interests, besides executing the regulatory decisions made by BDDK.

Highly volatile financial environment of the 1990s, costly experiences of fragmented regulatory system in the banking sector, and detrimental effects of politically motivated financial policy decision making led Turkish authorities agree to remove fragmented supervision and regulatory structure of the Turkish banking and create regulatory authorities potentially free of political influence. Toward this goal, the Banking Regulation and Supervision Agency (BDDK), sole authority in the Turkish banking sector, was established in June 1999. The aim of the BDDK is to regulate and monitor the financial markets to provide and maintain stability in financial markets along with sound banking activities and smooth functioning credit system. The adoption of Turkish Banking Law No. 5411 in 2005 is considered another important step towards more effective regulatory and executive authorities in Turkey's banking system.

\subsection{Banking Law in Turkey and Legal Provisions}

Private ownership is the most extensive real right over property. Article 1 of the Protocol to Convention for the Protection of Human Rights and Fundamental Freedoms governs right to possess and property protection stating "Every natural or legal person is entitled to the peaceful enjoyment of his possessions. No one shall be deprived of his possessions except in the public interest and subject to the conditions provided for by law and by the general principles of international law". 
Similarly, Article 354 of the Constitution of the Republic of Turkey grants right to property which is detailed in Article 683 of the Civil Code stating "The owner of property may, within the limits of law, use the property, deal with it as he pleases, and exclude others from interfering with it in any way". In addition, regarding banking sector in Turkey, Article 185 Turkish Banking Law No. 5411 governs acquisition and transfer of shares. Moreover, Article 74 of the Turkish Banking Law No. 5411 deals with an indispensable pillar for the protection of reputation stating "No real or legal person shall intentionally damage the reputation, prestige or assets of a bank or disseminate inaccurate news either using any means of communication defined in the Press Code No. 5187 or radio, television, video, internet, cable TV or electronic data communication devices and similar tools".

\section{Bank Asya's Managerial Takeover}

Higher profitability and superior performance than other participation banks and many other commercial banks in Turkey paved the way to Bank Asya grow bigger as shown by the constant rise in asset size in Figure 2 above up until 2013. The heyday of Bank Asya is ended due to the challenge between the governing political party and the Gülen movement, (aka Hizmet), "a worldwide civic initiative rooted in the spiritual and humanistic tradition of Islam and inspired by the ideas and activism of Mr. Fethullah Gülen" (Ebaugh, 2010). The bank found itself in a government initiated war since the shareholders of Bank Asya are known for their ties to the faith-based Gülen movement.

In February 2014, though allowing limited time for submission, the BDDK claimed that the main shareholders of Bank Asya failed to submit documents including criminal records, audited financial records, tax records of the past five years, property records and accounts in other banks to the agency. BDDK's insistency on the missing minor documents was only towards Bank Asya whereas none of the other banks operating in Turkey were under such pressure. BDDK interpreted the lack of aforementioned documents as a major transparency problem in Bank Asya's organizational and partnership structure. Therefore, in spite of Bank Asya's robust capital structure, TMSF had taken control of Bank Asya on Feb. 3, 2015 based on decision made by the BDDK on the provision that requires banks to have 'a transparent and open partnership and organizational scheme that does not obstruct the efficient auditing of the institution'. State-owned Anatolia news agency reported at 10:09 p.m. that "the BDDK had determined that Bank Asya had

\footnotetext{
${ }^{4}$ Right to property ARTICLE 35 - Everyone has the right to own and inherit property. These rights may be limited by law only in view of public interest. The exercise of the right to property shall not contravene public interest. (Constitution of the Republic of Turkey)

${ }^{5}$ ARTCILE 18, $5^{\text {TH }}$ PASSAGE - The shareholders with qualified shares shall be required to meet the criteria applicable to founders. The shareholders with qualified shares who do not bear the conditions required for founders any more shall not benefit from the shareholder rights other than dividends. In such cases, other shareholder rights shall be used by the Fund, upon the notification of the Agency. Such shareholders shall not use their preferential rights until the rate of their direct or indirect shares in the capital fall below ten percent. (Turkish Banking Law No. 5411.)
} 
failed to submit information and documents concerning 132 of the bank's 185 privileged shareholders, leading to uncertainty with respect to those shareholders". Therefore, Bank Asya's 63\% (majority) of the qualified shares were transferred to the disposal of the TMSF. A natural question "Given that Bank Asya has been operational since 1996, is it only now that the authorities have noticed the bank's failure to submit information and documents concerning privileged shareholders?" emerges as raised by Umut Oran, a parliamentarian for the main opposition Republican People's Party, to Deputy Prime Minister Ali Babacan in charge of economic and financial affairs. The question remarks the scepticism raised by many economists underlying the timing and politically motivated flavor of the operation.

In addition to TMSF had taken control of majority shares and management of Bank Asya on Feb. 3, 2015, the decision by the BDDK to hand over managerial control of Bank Asya fully to the TMSF on Friday May 29 2015, just few days before the country's general election on June 7 , has been criticized on many grounds. Fitch Ratings has called the episode a "black mark" on Turkey's prudent banking regulations since the 2001 financial crisis (Peker, 2015). Durmuş Yilmaz, former Chairman of the Central Bank of the Republic of Turkey, Doğan Cansızlar, former Chairman of Capital Markets Board of Turkey, Prof. Mehmet Altan of Istanbul University, Prof. Eser Karakas of Bahçeşehir University and many others criticized the takeover decision considering it a politically motivated move deliberately provoking a bank run (Today's Zaman, 2015) ${ }^{6}$. Turkey's President Recep Tayyip Erdoğan addressing the Turkish Industry and Business Association in September 2014 stated that "No effort is underway to cause the bankruptcy of a bank. That bank is already bankrupt. They are carrying water by hand to keep it afloat." (Çetingüleç, 2015). Citing the President's speech, considered by many a violation of Article 74 of the Turkish Banking Law No. 5411 regarding protection of banks' reputation, Bozkurt (2015) considers the takeover decision not only lacking financial and legal grounds but also the decision taken upon orders from President Recep Tayyip Erdoğan.

Quite interestingly, clients and loyal depositors rushed to Bank Asya branches to show solidarity, in order to initiate new accounts and/or deposit funds even after pro-government media announcements against Bank Asya and President Recep Tayyip Erdoğan's speech violating the banking law to protect the reputation of banks (Sezer, 2014). A depositor interviewed said, "We came over not to withdraw money, but to deposit some. We'll be selling our wedding rings and bracelets to keep our bank standing." This event is exceptional because, usually when there is even a rumor signaling weakness of a financial institution, typical depositors rush to withdraw money from the bank. In the case of Bank Asya, just the opposite happened where clients shouldered Bank Asya to stay afloat. Indeed, the depositors were manipulated to withdraw their money so that the bank would

\footnotetext{
${ }^{6}$ Eser Karakaş is Professor of Economics at Bahçeşehir University. Mehmet Altan is Professor of Economics at Istanbul University.
} 
consequently violate banking liquidity constraints and the takeover would have legal ground. The bank administration announced this key fact to its depositors and asked them to keep their money and even increase the amount, if they were able to. That is why many Bank Asya customers deposited more money.

Gertler and Kiyotaki (2013) develop a macroeconomic model of banking with similar notion of bank runs in Diamond and Dybvig (1983) to show an increase in the perceived likelihood of a bank run has harmful effects on the economy even if a bank run does not materialize. Takemura and Kozu (2009) study the relationship between individual depositor behaviour and factors behind them. Financial markets and banks have vital role for economic growth and development (McKinnon, 1973; Shaw, 1973; Rousseau and Sylla, 2003). Considering the vital role of banks and contagion nature of bank runs, skepticism on politically motivated decision making by governmental and banking authorities may indispensably have fatal consequences for financial and macroeconomic stability (Allen and Gale, 2000).

\subsection{Facts and Figures}

Bank Asya, established as the $6^{\text {th }}$ participation bank in 1996, is the first participation bank in Turkey that started selling 26 percent of its shares through initial public offering in 2006. The share in public hands doubled in about eight years to more than 50 percent by the end of 2014 .

The number of Bank Asya branches was 15 a year after the inception in 1997. The number of branches increased to 25 in 2000, 72 in 2005, 158 in 2009 and 281 in 2014 an indication of the good performance by Bank Asya over time. The bank had a stable progress as reflected by the rise in number of branches and staff size shown in Table 1 especially during the period of 2010 until the third quarter of 2014.

Table 1. Staff and Branch Figures of Bank Asya

\begin{tabular}{|l|c|c|c|c|c|c|c|c|c|c|c|}
\hline & $\mathbf{2 0 1 0}$ & $\mathbf{2 0 1 1}$ & $\mathbf{2 0 1 2}$ & $\begin{array}{c}\mathbf{2 0 1 3} \\
\text { Q1 }\end{array}$ & $\begin{array}{c}\mathbf{2 0 1 3} \\
\text { Q2 }\end{array}$ & $\begin{array}{c}\mathbf{2 0 1 3} \\
\text { Q3 }\end{array}$ & $\begin{array}{c}\mathbf{2 0 1 3} \\
\text { Q4 }\end{array}$ & $\begin{array}{c}\mathbf{2 0 1 4} \\
\text { Q1 }\end{array}$ & $\begin{array}{c}\mathbf{2 0 1 4} \\
\text { Q2 }\end{array}$ & $\begin{array}{c}\mathbf{2 0 1 4} \\
\text { Q3 }\end{array}$ & $\begin{array}{c}\mathbf{2 0 1 4} \\
\text { Q4 }\end{array}$ \\
\hline Staff & 4,266 & 4,542 & 5,064 & 5,109 & 5,146 & 5,182 & 5,075 & 5,027 & 4,819 & 4,033 & 3,210 \\
\hline Branch & 175 & 200 & 251 & 251 & 269 & 281 & 281 & 281 & 281 & 281 & 200 \\
\hline Staff/Branch & 24.4 & 22.7 & 20.2 & 20.4 & 19.1 & 18.4 & 18.1 & 17.9 & 17.1 & 14.4 & 16.0 \\
\hline
\end{tabular}

Bank Asya shares started to appear in the ISE 30, a main indicator of the Turkish national stock market, in $2007^{7}$. In 2012, the first abroad branch was inaugurated in Erbil, Iraq, and the first abroad representative in India was established. In 2013,

\footnotetext{
${ }^{7}$ ISE 30 (Istanbul Stock Exchange 30), composed of the top thirty (List A or List B) leading stocks of real estate, investment trusts, and venture capital investment trust companies traded on Collective Products Market, is a capitalization-weighted index used as a main indicator of the Turkish national stock market besides ISE 100 and ISE 50.
} 
amounts of 125 million TL and 250 million USD sukuk (Islamic equivalent of bonds) were provided from global financial markets (Islamic Development Bank). Table 2 displays key financial performance indicators for Bank Asya covering the periods of 2008 to 2013. The assets of Bank Asya increased from 8,109 million TL in 2008 to 27,785 million TL in 2013. Cash loans plus leasing, securities, deposits, funds borrowed and equities have constantly and steadily increased, as well. According to Table 2, the average annual year-to-year growth rate is positive for all items except net profits. Although the net profit is satisfactory, it declined from 247 million TL in 2008 to 181 million TL in 2013 mainly due to overall regressive factors influencing the Turkish banking sector and Bank Asya's firm specific strategic decisions. Skubik (2009) explores the advantages of disparate analyses belonging to shariahcompliance by addressing how a Gülen-like religion-state symphonia can evolve.

Table 2. Key Financial Performance Indicators (in million TL)

\begin{tabular}{|l|c|c|c|c|c|c|c|}
\hline & $\mathbf{2 0 0 8}$ & $\mathbf{2 0 0 9}$ & $\mathbf{2 0 1 0}$ & $\mathbf{2 0 1 1}$ & $\mathbf{2 0 1 2}$ & $\mathbf{2 0 1 3}$ & y/y \\
\hline Assets & 8,109 & 11,609 & 14,513 & 17,190 & 21,390 & 27,785 & $30 \%$ \\
\hline Cash Loans +Leasing & 6,381 & 8,355 & 11,060 & 13,452 & 16,307 & 21,257 & $30 \%$ \\
\hline Securities & 30 & 161 & 474 & 858 & 800 & 1,273 & $59 \%$ \\
\hline Deposits & 5,843 & 9,137 & 11,167 & 12,397 & 15,742 & 18,512 & $18 \%$ \\
\hline Non Cash Loans & 10,215 & 8,886 & 9,227 & 9,349 & 7,977 & 9,338 & $17 \%$ \\
\hline Funds Borrowed & 458 & 191 & 622 & 1,458 & 1,815 & 4,352 & $110 \%$ \\
\hline Shareholder's Equity & 1,404 & 1,708 & 1,942 & 2,137 & 2,349 & 2,511 & $7 \%$ \\
\hline Net Profit & 247 & 301 & 260 & 216 & 190 & 181 & $-5 \%$ \\
\hline
\end{tabular}

We add data from the third and fourth quarters of 2014 for Bank Asya under the control of the TMSF to Table 2 to obtain Table 3. In Table 3, we illustrate the significance deterioration in the bank's performance after the state seized Bank Asya. The impact of the unjust seizure and reputation damaging political campaign against Bank Asya is apparent in Table 3 as the negative year-to-year and/or quarter-to-quarter growth rates reveals.

Table 3. Key Financial Performance Indicators (in million TL)

\begin{tabular}{|l|c|c|c|c|c|}
\hline & $\mathbf{2 0 1 3}$ & $\mathbf{2 0 1 4 Q 3}$ & $\mathbf{2 0 1 4 Q 4}$ & $\mathbf{y / y}$ & $\mathbf{q} / \mathbf{q}$ \\
\hline Assets & 27,785 & 16.493 & 13.68 & $-17 \%$ & $-51 \%$ \\
\hline Cash Loans+Leasing & 21,257 & 12.301 & 9.407 & $-24 \%$ & $-56 \%$ \\
\hline Securities & 1,273 & 1.101 & 770 & $-30 \%$ & $-40 \%$ \\
\hline Deposits & 18,512 & 10.075 & 8.887 & $-12 \%$ & $-52 \%$ \\
\hline Non Cash Loans & 9,338 & 8.036 & 6.78 & $-16 \%$ & $-27 \%$ \\
\hline Funds Borrowed & 4,352 & 2.245 & 1.764 & $-21 \%$ & $-59 \%$ \\
\hline Shareholders' Equity & 2,511 & 2.272 & 1.705 & $-28 \%$ & $-35 \%$ \\
\hline Net Profit & 181 & -301 & -564 & - & - \\
\hline
\end{tabular}

Table 4 is built to show the main financial indicators for Bank Asya, participation banking and the whole banking sector in Turkey for comparison. The table is constraint with the last quarter of 2013 the date right before the state intervention 
to Bank Asya to show how it was performing prior to state intervention. Bank Asya's figures are higher than the participation banking and banking sector averages for all periods in terms of asset quality.

Table 4. Main financial indicators of Bank Asya, participation banks and the banking sector in Turkey (all figures but staff/branch are in \%)

\begin{tabular}{|l|c|c|c|c|c|c|c|c|c|}
\hline & \multicolumn{3}{|c|}{ Bank Asya } & \multicolumn{3}{c|}{ Participation Banks } & \multicolumn{3}{c|}{ Banking Sector } \\
\hline KPIs & $\begin{array}{c}\mathbf{2 0 1 3} \\
\mathbf{Q 4}\end{array}$ & $\begin{array}{c}\mathbf{2 0 1 3} \\
\mathbf{Q 3}\end{array}$ & $\begin{array}{c}\mathbf{2 0 1 2} \\
\mathbf{Q 4}\end{array}$ & $\begin{array}{c}\mathbf{2 0 1 3} \\
\mathbf{Q 4}\end{array}$ & $\begin{array}{c}\mathbf{2 0 1 3} \\
\mathbf{Q 3}\end{array}$ & $\begin{array}{c}\mathbf{2 1 2} \\
\mathbf{Q 4}\end{array}$ & $\begin{array}{c}\mathbf{2 0 1 3} \\
\mathbf{Q 4}\end{array}$ & $\begin{array}{c}\mathbf{2 0 1 3} \\
\mathbf{Q 3}\end{array}$ & $\begin{array}{c}\mathbf{2 0 1 2} \\
\mathbf{Q 4}\end{array}$ \\
\hline 1-AssetQuality & & & & & & & & & \\
\hline NPL Ratio & 5.32 & 3.82 & 3.98 & 3.45 & 3.15 & 3.08 & 2.80 & 2.80 & 2.92 \\
\hline NPL Coverage & 44.50 & 58.90 & 65.80 & 64.20 & 63.70 & 75.10 & 76.40 & 75.40 & 75.20 \\
\hline Specific Cost of Risk, (q) & 2.94 & 2.24 & 2.08 & 2.03 & 1.46 & 1.97 & 1.07 & 1.04 & 1.48 \\
\hline 2-Efficiency & & & & & & & & & \\
\hline PSE / PSI & 48.0 & 44.2 & 45.2 & 47.9 & 47.6 & 50.5 & 47.9 & 46.0 & 53.1 \\
\hline Cost/ Income & 55.3 & 48.1 & 54.5 & 49.6 & 47.6 & 48.8 & 49.3 & 46.5 & 39.4 \\
\hline NFCI/ OPEX & 34.3 & 43.4 & 39.5 & 42.9 & 49.6 & 49.3 & 46.7 & 47.1 & 49.0 \\
\hline Staff/ Branch & 18.1 & 18.4 & 20.2 & 17.6 & 18.0 & 18.7 & 17.9 & 18.1 & 18.3 \\
\hline 3-Capitalization & & & & & & & & & \\
\hline CAR & 14.27 & 14.22 & 13.60 & 14.00 & 14.35 & 13.91 & 15.30 & 15.74 & 17.86 \\
\hline 4-Profitability & & & & & & & & & \\
\hline NIM & 4.40 & 4.83 & 5.79 & 4.30 & 4.30 & 5.05 & 4.17 & 4.15 & 5.41 \\
\hline RoAA & 0.28 & 0.90 & 0.70 & 1.23 & 1.34 & 1.27 & 1.17 & 1.51 & 1.97 \\
\hline RoAE & 3.15 & 9.82 & 6.20 & 13.00 & 13.80 & 12.10 & 10.10 & 12.90 & 15.10 \\
\hline 5-Leverage & & & & & & & & & \\
\hline Loan / Deposit & 114.8 & 108.9 & 103.6 & 104.3 & 106.0 & 101.8 & 111.0 & 109.9 & 103.1 \\
\hline Non Cash / Cash Loans & 43.9 & 43.4 & 48.9 & 51.8 & 51.7 & 54.6 & 31.8 & 30.9 & 30.3 \\
\hline
\end{tabular}

Table 4 indicates the performance of Bank Asya than the participation banks in Turkey as well as the banking sector. In terms of efficiency, Bank Asya's performance is similar to the participation banking and the overall banking sector in general while Bank Asya's staff/branch ratios are slightly better. In terms of capitalization ratios Bank Asya's is no below the performance of the participation banks and overall banking sector. In terms of profitability, NIM figures are slightly better for Bank Asya, and both RoAA and RoAE are lower. Finally, Bank Asya has higher loan/deposits leverage ratio whereas the bank's non-cash/cash loan ratio is lower than participation banks in Turkey. The main financial indicators revealed by Table 4 confirm that Bank Asya was operating with similar performance to that of other participation banks and the Turkish banking sector in general with sometimes lower and sometimes higher scores over the period under investigation.

With these indicators and as a consequence of the analysis by internationally recognized Moody's Credit Rating Agency, Bank Asya was granted Caa1 for long term FX and TL deposits, E for financial strength and Ca for foreign Sukuk. The granted rating proves that Bank Asya was a qualified investable enterprise as of 16 December 2014. This is partly the consequence of proper auditing over all banks 
after the 2001 crisis of Turkey. Similarly, the rating to KuveytTürk was BBB for long term issuer default rating and $\mathrm{F} 3$ for short term issuer default rating from Fitch. Another participation bank Al Baraka was rated BB+ for long term and B for short term by S\&P.

Figure 3 depicts the evolution of the closing price of Bank Asya traded at the Istanbul Stock Exchange (ISE). As the figure shows, the performance of Bank Asya depreciated with share prices declining from over 2.50 in 2013 to about 0.50 in late 2014 and early 2015 causing the bank's shareholders experience unexpected losses. Considering the public statements made by government officials against Bank Asya starting late 2013 and the TMSF's takeover decision in the first quarter of 2014, one can't think without granting the deteriorating influence of such opposing actions on Bank Asya's performance in ISE that started late 2013.

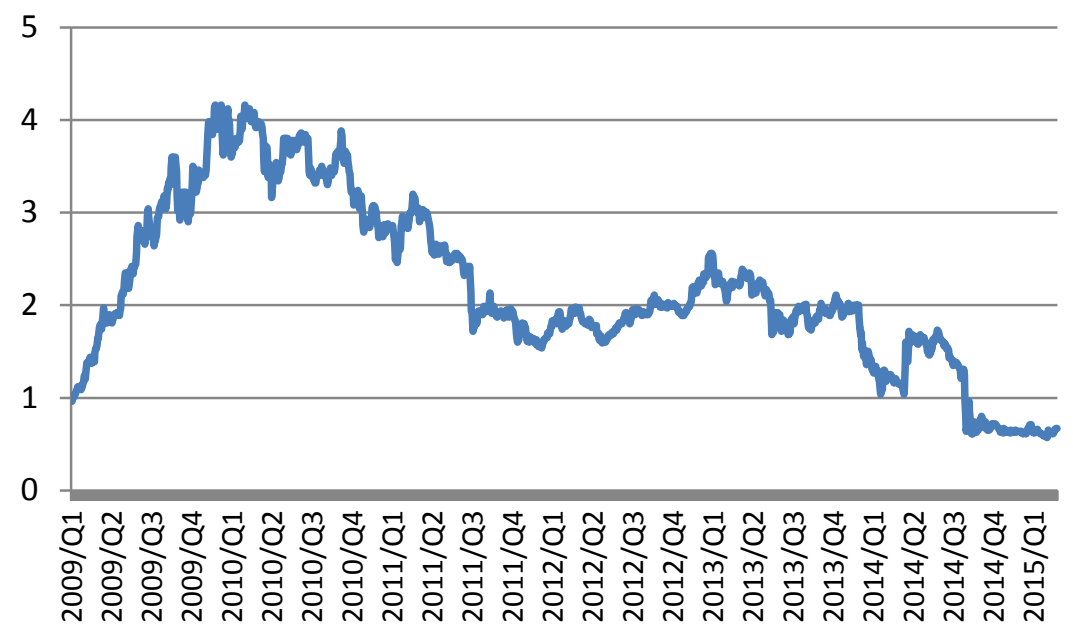

Figure 3. Closing price of Bank Asya shares, TL

Source: Borsa Istanbul

\subsection{Similar Cases to Bank Asya}

The case of Bank Asya is not the only example in the history of politically motivated takeovers, nationalizing and/or forcing private enterprises for bankruptcy by the governmental authorities. Though there are few more seizure examples with similar attributes across the globe, cases with similar qualities to Bank Asya case are not much. Managerial takeover followed by nationalizing and forcing for bankruptcy of Kentbank of Turkey in 2001 and government seizure of Banco Federal of Venezuela in July 2010 are two recent episodes.

Kentbank, a private bank established in 1992 by Süzer Holding, suffered a lot due to banking crisis of November 2000 and financial crisis of February 2001 that brought government authorities put the bank to close watchlist. Later, in July 2001, the 
BDDK transferred Kentbank to the TMSF on the basis of weakness in its balance sheet and alleged abuses in loan decision making to its affiliated companies and subsidiaries. Kentbank's banking license was revoked as of December 28, 2001 and the liquidation process was initiated which was revoked later and the bank was merged under Bayındırbank in April 2002. Mustafa Süzer, founder and primary shareholder who controlled more than $99 \%$ of the Kentbank capital, filed a case against the BDDK takeover decision to the Council of State of Turkey. Süzer won the case where Council of the State expressed in its verdict that Kentbank decision by the BDDK was baseless and the bank should be returned back to its primary shareholder. Following the affirmative decision by the Turkey's Council of the State, Süzer applied for banking license to be reissued which was declined by the BDDK. After exhaustion of domestic legal remedies, Süzer group appealed to the European Convention on Human Rights (ECtHR) against Turkish government in 2005. Süzer group argued the seizure of Kentbank by the BDDK during the 2001 crisis was unjust, damaged its group reputation and hence demanded a monetary compensation of 4.1 billion USD. After a long judicial process, in 2012, the ECtHR ruled in favor of Süzer group that could potentially set a precedent for the case of Bank Asya in Turkey ${ }^{8}$. The ruling stated that Turkish government had violated the fair judgment and property rights clauses of the ECtHR Convention and seizure of the bank was unjust ${ }^{9}$. The court gave the Turkish government and Kentbank six months to reach a compromise to solve the issue.

Government seizure of Banco Federal in July 2010, Venezuela's eighth largest bank, seems to have similar attributes to the case of Bank Asya as well. Although President Chávez claimed the seizure of Banco Federal by regulators was a necessary step to protect clients because the bank was broke, the bank's owner, Nelson Mezerhane, a Chávez opponent, denied accusations and claimed the bank takeover was illegal and for political reasons ${ }^{10}$. The U.S. Department of State's 2010 Human Rights Report on Venezuela reports President Chávez's interest in "using the shares the government obtained through its intervention of Banco Federal to gain representation on the executive board of Globovision, the major privately owned and opposition-oriented cable news station, which broadcasted nationally on cable and over the air in Caracas and Valencia". The report also considers the Venezuelan government's bank seizure decision as "an apparent effort to change the Globovision's editorial line" an indicator for the lack of economic basis in the seizure of Banco Federal.

\footnotetext{
${ }^{8}$ Bank Asya's shareholders filed cases against the seizure decision by BDDK to Administrative Court to regain control of shares. The shareholders argue that the takeover of the bank was not legally possible under banking law and, after exhaustion of domestic legal remedies, they will appeal to the ECTHR in case the Turkish courts fail to provide a fair judicial treatment.

${ }^{9}$ The ruling stated there had been " $a$ violation of Article 1 of Protocol No. 1 to the ECTHR Convention on account of the measures taken by the State depriving Kentbank of its property and the failure to enforce the administrative court judgments in the bank's favor".

${ }^{10}$ Nelson Mezerhane filed a lawsuit against Venezuelan government for one billion USD (Anderson, 2011).
} 


\section{Political and Legal Aspects of Expropriation}

Benevolent governing authorities struggle to provide more stable political, economic, and financial environment for prosperity. In recognition of the importance of banking sector and contagion nature of events in the closely connected financial sector, recent experiences during the global financial crisis of 2007-08 have revealed too big to fail phenomenon that governments usually are willing to provide assistance to large banks that would otherwise go capital inadequacy driven bankruptcy which would pose serious risks to the financial system and have threatening consequences for the broader economy (Wheelock, 2012). The case of Bank Asya suggests the opposite where a healthy national bank with adequate capital is forced to bankruptcy by government authorities with heavy political considerations and little attention paid to consequences that have potential to impede the functioning of the financial system. The lack of economic basis for the seizure shows up further while the political aspirations behind the actions against Bank Asya crystallize and come on the scene when one thinks how unlikely it is for the timing of the unusual expropriation of Bank Asya occurring at the same time as the initiatives of the governing political party, Justice and Development Party (AKP), against the Gülen movement.

AKP emerged as a spinoff from the traditional Islamic 'National View' (Milli Görüş in Turkish) group claiming to be a conservative democratic party with full aim of integration to the European Union. With this discourse, AKP was able to collect votes from all layers of the society and was evaluated as a rescue out of Turkey's deepest financial crisis of February 2001 after the World War II. The party became extremely successful up until the global financial crisis of 2007-08. The party came to power in 2002 with $34.3 \%$ of the vote and achieved to occupy about two-thirds of the seats in the Grand National Assembly three general elections in raw with 66 percent in 2002, 62 percent in 2007, and 59.3 percent in 2011.

2010 was a milestone in the history of Turkey and governing party where constitutional changes suggested by the party were adopted by 58 percent of the voters in a highly polarized referendum. These amendments helped hindering the monopoly of the secularist judges in the judiciary system especially in the supreme courts besides the Council of Judges and Public Prosecutors (HSYK). This was a dramatic change in Turkish history executive and justice system giving the rein of power to AKP. Along with the adoption of the constitutional changes one of a few authorities that may mitigate the party dominance was eliminated. Another contribution of the constitutional amendments in 2010 was backspacing the influence of the military (Özbudun, 2014).

Hale and Özbudun (2010) indicate "it appeared that at the beginning of 2009 the AKP was at a crossroads. It might either return to its old policy of vigorously pursuing reformist path with the ultimate aim of becoming an EU member, or to compromise with the state elites and accept the status quo perhaps with some 
minor improvements". Maybe the accomplishment and domination of the party at all challenges tried positioned it to a very authoritarian path. As Özbudun, 2014 states “Prime Minister Erdoğan's increasing references to Islamic themes such as his promise to raise 'pious generations', the introduction of more Islamic themes on an optional basis - into the school curricula, his statements against abortion, his insulting words about alcohol drinkers and unmarried boy and girl students sharing the same house are cases in point. These were accompanied by a law intended to restrict alcohol consumption." Growing popularity in adoption of a language referring directly to the religious terminology brought excess power which seemed to result in divergence from religious references for constant reproduction of political power. Over time, Erdoğan's degrading remarks towards different segments of the society seemed to contribute a lot provoking inner reaction against himself, even around his very close cohorts (Daily Sabah Politics, 2014).

The reaction suppressed in the society came out of control at Gezi protests which started with innocent environmentalist attitude against trees to be cut in a redevelopment plan of Gezi Park in Istanbul with the aim of building a shopping center. Initially the protests were democratic, mild, and careful. Few days later, protests turned into street clashes between protestors and the police force. Many find AKP failed to administer the protest by using a harsh language against demonstrations which later led to five deaths and hundreds of injured. Gezi protests were the first event where civil society was accused to overturn Erdoğan government and his party by non-electoral ways. Unfortunately, these events paved the way to polarize the country even more where the ruling party was happy to plan converting similar reactions from religious citizens to votes in coming elections. A major strategy of the party was to use of a rhetoric based on a conspiracy theory placing domestic and foreign enemies of the country allying against the party where the party was placed as the unique contender against all such enemies (Bilgin, 2013; Amnesty International, 2013; Geyikci, 2015).

Another turning point event digressing the party to authoritarian route is the disclosure of the investigation claiming the greatest corruption charge to four ministers of the cabinet who would resign from the cabinet with no legal charges. Close relatives and companions of the four ministers, the general director of a state bank, bureaucrats and businessman close to the party administration were also under investigation. The evidence was deliberately arranged, and the claims were very serious and widespread to make anyone think that the charges can be extended to all parts of the party administration. Furthermore, there were serious claims against Erdoğan and his immediate family members.

After a short lived shock in response to the corruption cases claimed to be the greatest in the history of a century old Turkish Republic, the party notables launched a counter attack announcing that the corruption investigations were designed by unified enemies of Turkey including international actors and their collaborators in Turkey. The rhetoric used was a common one: Turkey was 
extremely successful and was becoming a threat to prominent western countries. It was claimed further that, the USA and Israel gathered with other enemies of Turkey, employed Hizmet to the bloc against the party to cut the route of the Turkey under AKP administration. Furthermore, in an abundantly conspiracy theory alike approach, the Gülen movement was accused of establishing an alleged Parallel State at bureaucracy and judiciary system along with betraying the country by collaborating with the enemies abroad. But, to the contrary, the movement is well known with its educational activities to establish peace worldwide (Esposito \& Yilmaz, 2010, and Ebaugh, 2010). As a result, anyone claimed to be associated with Gülen movement antagonized overnight. There was no need to consider the rule of law and justice since the movement was considered very dangerous and detrimental to economically growing country. Great effort was given to control the media for the sake of keeping media channels under direct control and sentence the media to silence when it comes to claimed corruption news. Appearance of all news regarding the corruption investigations is banned. Later, such bans are extended to almost any news that could be interpreted against the AKP government. While banning and silencing efforts were climbing up the ladder, Turkey fell five places to the $98^{\text {th }}$ spot with a drop in score from 5.63 to 5.12 out of 10 on Economist Intelligence Unit's Democracy Index during the periods of 2013 to 2014. According to World Press Freedom Index of Reporters without Borders for Freedom of Information (RSF), Turkey's ranking in press freedom, a powerful pillar of democracy, dropped to 154th place among 180 countries with a score of 45.8 in $2014^{11}$. Moreover, according to Transparency International's global Corruption Perception Index 2014, Turkey's perceived corruption level has worsened the most out of 175 countries with five points drop to 45 from 2013 to 2014. Pro-AKP media assumed that everyone opposing view against the party were ill-intended and all news - mostly without proofreading of correctness of the news - should be broadcast to convince the public that there were enemies unified against Turkey and their first target was AKP that fights against all such enemies for the good of the country.

According to Taraf, a Turkish daily newspaper, Erdoğan himself termed the movement as 'spies', 'agents', 'sub-contractors' of foreign forces, 'traitors', 'members of a gang', 'involved in political engineering', 'a state within a state', 'a parallel state', etc., and declared his intention of 'entering their dens and destroying them' (Özbudun, 2014). Along with such allegations, many judges, prosecutors and police officers claimed to be part of the alleged parallel state were expelled, arrested, and/or reappointed to other districts with prejudgment. Initiatives of AKP for extensive purge of political opponents in all spheres of life were resembled by many to McCarthyism like witch-hunt (Akyol, 2014).

\footnotetext{
${ }^{11}$ In 2002, when the ruling Justice and Development Party (AKP) came to power, Turkey ranked 99th out of 134 countries surveyed. The RSF describes the state of press freedom in countries within the range of 35-55 points as being in a "difficult situation".
} 
In the second stage of the campaign against the "fabricated" parallel state accusation, Erdoğan insistently announced that the country is under a serious threat and everyone including academics, bureaucrats, intellectuals, businessmen, and columnists fix their standing, he said "if you do not comply with us, then you are against us (and part of the enemy)". Some judges ruling against the will of the AKP are imprisoned as well as prosecutors with similar decisions.

One main factor to awaken many citizens was the deterioration of the economy beyond any media steering and the limitless wastage of the government. Indeed, AKP claimed that all seemingly wasteful expenditures are needed to prove the reputation of Turkey at the international arena, but it kept on losing its credibility since many AKP members became unbelievingly rich under the governing years of AKP.

The main reason behind the seizure of Bank Asya is not the inappropriate financial statement of the Bank but rather the sequence of political and judicial chronology of events revealed above. Bank Asya is assumed to be the hub financing the activities of the Gülen movement. Very surprisingly, the chairman of the BDDK had visited President Erdoğan the day before the seizure. Indeed, for a bank to be seized, its capital sufficiency ratio should be less than $12 \%$, but it was $18 \%$ for Bank Asya at the time of the seizure. Sami Karahan, Marmara University Faculty of Law professor specialized in Business Law, have stated that "There is a serious violation of the law going on here, they attempted to sink the bank, to destroy its financial structure. Yet despite everything, they weren't able to seize it on Feb. 3rd. They simply took over management with missing documentation as their excuse." He continued "When the bank still didn't fail despite the takeover, they started concocting various scenarios over the past four months," and added "They attempted to get hold of its database. They tried to destroy its balance sheet. They tried to get the bank in trouble by not submitting reports to inspectors. They tried everything they could. Despite this the bank still posted 13 million TL in profits by the TMSF's own admission. This drove them insane. The TMSF had seized the bank because of its failing finances. Then who sank the bank? If the bank's finances really are broken, it's because the TMSF's management sank the bank and then seized it". The contagion nature of events in the financial sector and unlawful measures taken against Bank Asya seem to have great influence on the exit decisions of HSBC and Citi from Turkish banking sector.

\section{Conclusion and Further Discussion}

In conclusion, this paper studies the seizure of Bank Asya by the state with reference to similar historical episodes. We discuss the detrimental implications of politically motivated bank seizures on financial stability when bank takeovers have no economic basis and such actions are taken without reference to capital adequacy ratios as set by internationally recognized regulatory organizations. Our analysis underline three fundamental principles: violation of private property 
rights, contagion nature of events in the financial sector, and excessive cost of unnecessary bank seizures without economic ground. Besides, such an expropriation has negative impact on the credibility of Turkey. As indicated by Doğan and Bozdemir (2014) credibility is crucial for countries like Turkey after inflation and interest rate management.

We mention the line of events in a chronological order for case of Bank Asya takeover by the TMSF along with applicable banking law rulings. We show that governmental banking sector regulatory authorities misinterpreted some of the banking law articles to impose an unjust pressure on Bank Asya while such misinterpretations were imposed just against Bank Asya and not on any other member bank operating in the Turkish banking sector. Moreover, we show how banking sector regulatory bodies neglected or failed to do their duty by prejudicially not executing one of the most important rule governing the protection of reputation of a bank while many including the President of Turkey constantly violating Article 74 of the Turkish Banking Law 5411 against Bank Asya.

We provide descriptive statistics regarding the banking sector in Turkey in general along with detailed information on participation banking and Bank Asya. We show that, although the share of participation banks in the overall banking sector is relatively small, the growth of the participation banking sector outpaces the general banking sector with promising and financially efficient outcomes. To shed light on the loss of economic and financial ground on the seizure of Bank Asya, we provide capital adequacy and main financial ratios along with figures and estimates obtained from Bank Asya's balance sheet. The figures confirms the bank's financial strength and compatibility with the Basel Accords and supervision recommendations on banking regulations issued by the Basel Committee on Banking Supervision that emphasizes capital adequacy as the main indicator of a bank solvency.

We provide an extensive account of political aspects regarding the seizure of Bank Asya to uncover the true motivation behind the seizure. We discuss how unlikely it is for the government orchestrated anti-Gülen movement operation to coincide by chance with the timing of Bank Asya seizure.

Seizure of Bank Asya with political motives is not the only example violating pillars of democracy and free market. Episodes of Kentbank of Turkey and Banco Federal of Venezuela have similar attributes to the case of Bank Asya. We provide anecdotal and chronological information of events regarding seizure of Kentbank and rulings by the internationally recognized courts along with human right reports on the measures taken against Banco Federal in order to understand the case of Bank Asya better and derive possible future consequences. We discuss how the ECtHR's ruling in 2012 addressing violation of fair judgment and property rights clauses of the ECtHR Convention and unjust bank seizure in favor of Kentbank shareholders could potentially set a precedent for the case of Bank Asya. 
Hasan GOCEN, Halit AKTURK \& Mehmet ORHAN

\section{Acknowledgement}

We would like to thank to the editor of EJBE, Prof Ali Coskun, for his kind and constructive help.

\section{References}

Akyol, M. (2014, Mar. 19). McCarthyism Comes to Turkey. The New York Times. Retrieved from http://www.nytimes.com/2014/03/20/opinion/akyol-mccarthyism-comes-toturkey.html? $r=1$

Anderson, C. (2011, Nov. 9). Foe of Venezuela's Chavez seeks \$1B for seizures. Bloomberg Business. Retrieved from http://www.businessweek.com/ap/financialnews/D9QTC6480.htm

Amnesty International (2013), Gezi Park Protests: Brutal denial of the right to peaceful assembly in Turkey. Retrieved from https://www.amnestyusa.org/sites/default/ files/eur440222013en.pdf

Bilgin, F. (2013), Turkey: Politics of Gezi Protests. Rethink Institute, Washington DC. Retrieved from http://www.rethinkinstitute.org/files/Bilgin\%20-\%20Gezi\%20Protests.pdf

Bozkurt, T. (2015, Jun. 3). Illegal Intervention in Bank Asya collapses. Today's Zaman. Retrieved from http://www.todayszaman.com/columnist/turhan-bozkurt/illegalintervention-in-bank-asya-collapses_382945.html

Çetingüleç, M. (2015, Feb. 10). Why Did Turkey Seize Bank Asya? Al-Monitor. Retrieved from http://www.al-monitor.com/pulse/originals/2015/02/turkey-erdogan-anti-west.html\#

Diamond, D. \& Dybvig, P. (1983). Bank Runs, Deposit Insurance, and Liquidity, Journal of Political Economy, 91, 401-419. http://dx.doi.org/10.1086/261155

Doğan, M.K. \& Bozdemir, G. (2014). The Effects of Credibility on Interest Rates in Turkey, Eurasian Journal of Business and Economics, 7 (14), 71-90.

Doğan, B. (2015, Apr. 9). Former CB governor: Bank Asya is strong, nation will suffer if gov't sinks it. Today's Zaman. Retrieved from http://www.todayszaman.com/anasayfa_former-cbgovernor-bank-asya-is-strong-nation-will-suffer-if-govt-sinks-it_377560.html

Ebaugh, H. R. (2010). The Gülen Movement: A Sociological Analysis of a Civic Movement Rooted in Moderate Islam. New York and Heidelberg: Springer. http://dx.doi.org/10.1007/978-1-4020-9894-9

El-Gamal, M. A. \& Inanoğlu, H. (2000). Islamic banking in Turkey (1990-2000) Boon or Bane for the Turkish Financial Sector? Proceedings of the Fifth Harvard University Forum on Islamic Finance: Dynamics and Development, Cambridge, Harvard University, 7-20.

Esposito, J.L. \& Yilmaz, I. (2010). Transnational Muslim faith-based peacebuilding: Initiatives of the Gülen Movement, European Journal of Economic and Political Studies, 3 (SI), 87-102.

Finkelman, P. (2006). Lynching and Mob Violence. In The Encyclopedia of African American history: 1619-1895: from the colonial period to the age of Frederick Douglass. (Vol. 1, pp. 307-313). Oxford, UK: Encyclopedia of African American History.

Franklin, A. \& Gale, D. (2000). Financial Contagion, Journal of Political Economy, 108, 1-33. http://dx.doi.org/10.1086/262109

Gertler, M., \& Kiyotaki, N. (2012). Banking, Liquidity and Bank Runs in an Infinite-Horizon Economy. Cambridge, NBER Working Paper No. 19129. 
Geyikci, S.Y. (2015). Gezi Park Protests in Turkey: A Party Politics View, The Political Quarterly, 85(4), 445-453. http://dx.doi.org/10.1111/1467-923X.12112

Hale, W. \& Özbudun, E. (2010). Islamism, Democracy and Liberalism in Turkey. London and New York: Routledge.

Islamic Development Bank (2015). What is Sukuk? A secure return through an ethical investment. $\quad$ Retrieved from http://thatswhy.isdb.org/irj/go/km/docs/documents/IDBDevelopments/Internet/thatswhy/ en/sukuk/what-is-sukuk.html

Kubat, M. (2014). Proceedings from 2nd Economics \& Finance Conference '14: Does Basel III Bring Anything New? A Comparison between Capital Accords Basel II and Basel III. Retrieved from http://iises.net/proceedings/2nd-economics-finance-conference-vienna/table-ofcontent ?cid $=4 \&$ iid $=19 \&$ rid $=1713$

McKinnon, R. I. (1973). Money and Capital in Economic Development. Washington, DC: Brookings Institution.

O'Byrne, D. (2014, October 17). Breaking the Bank Asya in Turkey. BNE Intellinews. Retrieved from http://www.bne.eu/content/story/breaking-bank-asya-turkey

Özbudun, E. (2014). AKP at the Crossroads: Erdoğan's Majoritarian Drift, South European Society and Politics, 19(2), 155-167. http://dx.doi.org/10.1080/13608746.2014.920571

Peker, E. (2015, May 31). Turkish Authorities Seize Bank Asya. The Wall Street Journal. Retrieved from http://www.wsj.com/articles/turkish-authorities-seize-bank-asya1433102306

Ritter, L. S., Silber, W. L., \& Udell, G. F. (2009). Principles of Money, Banking and Financial Markets 10th Ed. Boston: Addison-Wesley.

Rousseau, P. \& Sylla, R. (2003). Financial Systems, Economic Growth, and Globalization. In Bordo, M. D, Taylor, A. M., \& Williamson, J. G. (Eds.), Globalization in Historical Perspective (373-416). Chicago: University of Chicago Press. Retrieved from http://www.nber.org/chapters/c9594.pdf

Sezer, S. (2014, October 5). Loyal depositors shoulder Turkey's Bank Asya while political war rages. Reuters. Retrieved from http://www.reuters.com/article/2014/10/05/us-turkeybankasya-idUSKCNOHUOB920141005

Shaw, E. (1973). Financial Deepening in Economic Development. New York: Oxford University Press.

Skubik, D.W. (2009) Fethullah Gülen, Islamic Banking, and Global Finance, In International Corporate Responsibility Series, A Survey of International Corporate Responsibility, Vol 4, 289-304.

Takemura, T. \& Kozu, T. (2009). An Empirical Analysis on Individuals' Deposit Withdrawal Behaviors Using Data Collected through a Web-Based Survey, Eurasian Journal of Business and Economics, 2 (4), 27-41.

U.S. Department of State, Bureau of Democracy, Human Rights, and Labor. (2011). 2010 Human Rights Report: Venezuela. Retrieved from http://www.state.gov/i/drl/rls/ hrrpt/2010/wha/154523.htm

Wheelock, D. C. (2012). Too Big To Fail: The Pros and Cons of Breaking up Big Banks, St. Louis FED's The Regional Economist, Oct., 10-11. 